Review

\title{
Art of Music, as Harmony of the Spheres and Autism Spectrum Disorder
}

\author{
Bharathi Geetha *, Thangaraj Sugunadevi, Babu Srija, Nagarajan Laleethambika \\ and Vellingiri Balachandar*
}

Human Molecular Genetics and Stem Cell Laboratory, Department of Human Genetics \& Molecular Biology, Bharathiar University, Coimbatore, 641046 Tamil Nadu, India; suguna042@gmail.com (T.S.); srija.babu93@gmail.com (B.S.); drlalithambika@yahoo.com (N.L.)

* Correspondence: drpga2002@gmail.com (B.G.); geneticbala@yahoo.co.in or geneticbala@gmail.com (V.B.); Tel.: +91-814-405-2274 (B.G.); +91-422-242-2514 (V.B.); Fax: +91-422-242-2387 (V.B.)

\begin{abstract}
Music has the innate potential to reach all parts of the brain, stimulates certain brain areas which are not achievable through other modalities. Music Therapy (MT) is being used for more than a century to treat individuals who needs personalized care. MT optimizes motor, speech and language responsibilities of the brain and improves cognitive performance. Pervasive developmentdisorder (PDD) is a multifaceted, neuro developmental disorder and autism spectrum disorder (ASD) comes under PDD, which is defined by deficiencies in three principal spheres: social connection with others, communicative and normal movement skills. The conventional imaging studies illustrate reduced brain area connectivity in people with ASD, involving selected parts of the brain cortex. People with ASD express much interest in musical activities which engages the brain network areas and improves communication and social skills. The main objective of this review is to analyze the potential role of MT in treating the neurological conditions, particularly ASD. Evidence based studies have reported the extensive therapeutic application of music on various part of the brain in a nonverbal child with autism through hearing or making music. Hence we hypothesized that MT intervention can improve the communication capacity in people with ASD, than customary neurorestoration therapy alone.
\end{abstract}

Keywords: Pervasive developmental disorder; Autism spectrum disorder (ASD); brain network; Theory of Mind (ToM); Music Therapy (MT); therapeutic effect

\section{Introduction}

Music therapy (MT) through music, addresses a number of emotional, cognitive, and social issues in human beings, also offers healing benefit to someone with disabilities or illness. The American Music Therapy Association (AMTA) explains MT as a clinical and evidence-based practice of music intervention to achieve personalized goals within a therapeutic relationship by a qualified professional, who has completed an approved music therapy program [1]. Music engages the central coordination of body movement by mirroring its various dynamics based discipline. It relates evidence based science to the creative, emotional, spiritual, energizing experiences of music for treating health related problems and to attain education related goals [2]. MT is also practiced to relieve labor pain, terminal illness pain and in physical rehabilitation such as stroke (which can lead to aphasia) rehabilitation [3].It may be effective in decreasing agitation, disabling initiation difficulties, and stimulating positive behaviors in a population with psychiatric, neuro-behavioral, 
developmental and degenerativedisorders. A current study reports the impact of MT among the neurologically affected children by improving their attention span, communicating skills and strongly recommends its use for other kind of disorders too[4]. Many researches have proved that listening to music improves emotional and cognitive functions of children with neurological problems $[3,5,6]$. Also the plasticity of the brain changes, if someone practices music and playing on an instrument for a long time $[7,8]$. Singing improves the symptoms associated with speech -motor difficulties [9].The hampered language system is adjacent to the left hemisphere, whereas a larger bi-hemispheric network involves singing or intoned speaking [10]. Music as a therapeutic tool mends the cognitive, sensory and a motor difficulty due to the central nervous system disorder is known as neurologic music therapy (NMT).NMT treatment is based on stimulating the parts of human brain for perception of music, also making of music and its outcome on nonmusical and behavioural functions [11].MT is one of the expressive therapyand has through its active and receptive formsenhances physical and mental health. Music relieves emotional stress, treats depression, anxiety and memory loss associated with several neurological disorders. Since biblical times, MT has been practiced worldwide [12]. As early as 400 B.C, Hippocrates II (c. 460 - c. 370 BC) a Greek physician, played music for mentally challenged patients. In the eighteenth century, people started to understand the relationship between the body, mind and the nervous system which paved the way to MT and from the mid-eighteenth century, many authors have reported the influence of music in treating the neurological disorders [13].MT was primarily practiced to treat children who demanded special care in the early to mid- $19^{\text {th }}$ century in USA and since then, MT has been practiced over 50 years [14]. From 1970s, nearly one hundred reports of MT in special education [15], a descriptive literature review from 1990-2006, forty three research articles related to clinical practice of MT in special education among children and young people from 3 to 20 years of age [14] have been identified. In 1729, Dr. Richard Browne from UK wrote the first English text book concerning music and medicine, "Medicina Musica" is a noteworthy document in the history of MT [16].World wars demanded an alternative form of treatment and thus, MT was introduced to manage and treat the sick and wounded population [17].In 1930, for the first time, MT was practiced to modify moods and to improve physical activity in an open psychiatric ward [18].

\section{Autism spectrum disorder (ASD), a world of complexity}

In 1943, Kanner, for the first time described ASD [19] and in 1944, Asperger reported about autistic psychopathy. His work was translated from German to English by Utah Frith in 1991 [20]. Until 1980's it was primarily treated as a psychiatric disorder and children were misdiagnosed as being schizophrenic [21].ASD is a group of multifaceted disorder, occurs approximately 6 to $22 \%$ per 1,000 children and statistically diagnosed more among men thanin women [CDC 2014]. The onset is early, the symptoms typically appear by 3 years [22] and can persist througout a person's lifetime.Presently, the cause of ASD is unknown, but assumed that, some people are genetically predispositioned along with other unexplained exogenous factors whichplay aforemostpart in the development of ASD. As per Diagnostic and Statistical Manual of Mental Disorders IV (DSMIV), Pervasive developmental disorders (PDD)includes Autism, Rett syndrome (RTT), childhood disintegrative disorder(CDD), Asperger's syndrome (AS) and pervasive developmental disorder-not 
otherwise specified(PDD-NOS) are chronically enduring conditions with a very few treatment options. As ASD individuals exhibit inadequate social, emotional exchange with minimal eye contact, deficit in non- verbal communicative behavior leads to difficulties in making along with maintaining friendship and repetitive, restricted actions (RRB's), all these make them to face lifelong difficulties in different social situations. Yet, there are no biological markers for autism, screening methods must focus on behavior.

\subsection{The definition of "Spectrum"}

The term "spectrum" in ASD denotes an array of symptoms, varying degree of social skill impairments and repetitive behavior. In DSM - IV, one of the primary ASD is Autistic Disorder. This disorder shares many of the same behaviors with AS, PDD-NOS, but differs in terms of time on beginning of the behaviors, the defined form of problems and severity. PDD includes RTT and CDD, but they are no more included in the "spectrum", as new diagnostic criteria, DSM -V has been developed [23]. ASD or 'classic autism' is diagnosed principally based on the International Statistical Classification of Diseases and Related Health Problems (ICD), which is a medical classification list by the World Health Organization (WHO) and The Diagnostic and Statistical Manual of Mental Disorders-DSM, issued by the American Psychiatric Association (APA).ICD-10 and DSM-V, both describe behavioral criteria and specify expected age of onset. Only about $10 \%$ of individuals diagnosed with autism also have other chromosomal abnormalities.ASD is frequently reported with some of the known genetic disorders, pathological conditions, which is termed as comorbidity, and most of the conditions are treatable also $[24,25,26]$. According to the DSM- $V$, for a diagnosis of ASD, a child must have hadsymptoms from early childhood with reduced social communication skills, fixated interests and monotonous activities. As per DSM - V, ASD consists of Asperger syndrome (AS) which shows delayed cognitive function, language skill and if the whole criteria for autism or Asperger syndrome are not met, then the disorder can be termed as PDD-NOS.

\section{Genes and their intricate role in ASD}

A current development in genetic screening technique explores chromosomal abnormalities in association with ASDs. Approximately $20 \%$ of ASD is in connection with single gene defects, such as Cowden disease and RTT, but the source of the condition cannot be identified among the rest of the individuals [31]. Hence it has been hypothesized that the individual microdeletions, duplications and other mutations can cause ASDs. Interactions of no less than 10 genes in the causation of autism have been confirmed from the data of whole-genome screen of multiplex family studies. Researches have been projected that numerous genes are involved in the formation of intricate genetic risk of ASDs $[32,33,34,35]$. The risk is carried out in a non-Mendelian fashion and the identification is difficult because each of the genes show small population effect size due to the presence of candidate genes [36]. A supposed speech and language loci at chromosome (chr.) 7q31 to q33 appears to be linked with autism, whereas association with numerouslocus warrants further research. Frequent cytogenetic abnormalities at the chr.15q11-q13 locus are reported in people 
with autism, and a "chromosome 15 phenotype" was coined for a person with chr. 15duplication.On chromosome 7q22-q33, a number of candidate genesare identified: FOXP2, RAY1/ST7, IMMP2L and the RELN genes, on chr. -15q11-q13,GABA (A) receptor subunit and UBE3A genes. On chr. 17q11-q12, different alleles of the serotonin transporter gene (5-HTT) are frequently seen in autistic individuals,compared to the healthy individuals.

Table 1.ASD related syndromes caused by Single Gene Mutation

\begin{tabular}{|c|c|c|c|c|c|}
\hline Chromosome & $\begin{array}{l}\text { Gene/ } \\
\text { loci }\end{array}$ & $\begin{array}{l}\text { Phenotype } \\
\text { (human/mouse) }\end{array}$ & Mechanism involved & \begin{tabular}{|l} 
Risk of \\
autism
\end{tabular} & Reference \\
\hline $7 q 35-q 36.1$ & CNTNAP2 & $\begin{array}{l}\text { EPI syndrome(Recessive), } \\
\text { ASD, ADHD, TS, OCD }\end{array}$ & $\begin{array}{l}\text { Rearrangement of } \\
\text { chromosomes and } \\
\text { larger deletions, } \\
\text { transcription factor } \\
\text { FOXP2 disruption, SNP }\end{array}$ & $\begin{array}{l}\text { Not } \\
\text { decisive }\end{array}$ & $\begin{array}{l}\text { Vernes et al., } \\
2008 \text { Sehested } \\
\text { et I.,2010, } \\
\text { Newbury et al., } \\
2011 \text {, } \\
\text { Poot et al.,2010 }\end{array}$ \\
\hline $8 q 12.1$ & CHD7 & CHARGE & $\begin{array}{l}\text { CHD } 7 \text { gene Mutations, } \\
\text { deletions, SNP, } \\
\text { Chromatin re modeled; } \\
\text { transcription factor } \\
\text { FOXP2 disruption }\end{array}$ & $15-50 \%$ & $\begin{array}{l}\text { Teramitsu et } \\
\text { al.,2004,Panaitof } \\
\text { et al.,2010 }\end{array}$ \\
\hline $9 q 34.13$ & TSC1 & Tuberous Sclerosis type I & $\begin{array}{l}\text { TSC1gene mutation and } \\
\text { hyper activation of the } \\
\text { downstream mTOR } \\
\text { pathway increases cell } \\
\text { growth and } \\
\text { proliferation. }\end{array}$ & $\begin{array}{l}\text { Not } \\
\text { decisive }\end{array}$ & $\begin{array}{l}\text { Showbrige et } \\
\text { al., } 2010\end{array}$ \\
\hline $10 q 23.31$ & PTEN & Cowden disease & Mutation of gene PTEN & $\begin{array}{l}\text { Not } \\
\text { decisive }\end{array}$ & $\begin{array}{l}\text { Conti et al., } \\
2011\end{array}$ \\
\hline 11q13.4 & DHCR7 & $\begin{array}{l}\text { Smith-Lemli-Opitz } \\
\text { syndrome }\end{array}$ & $\begin{array}{l}\text { Mutations of gene } \\
D H C R \text { leads deficiency } \\
\text { of cholesterol synthesis } \\
\text { and accumulaties 7- } \\
\text { dehydrocholesterol }\end{array}$ & $\begin{array}{l}15-50 \% \\
3 \%\end{array}$ & $\begin{array}{l}\text { Hartshorne et } \\
\text { al., 2005, } \\
\text { Johansson et } \\
\text { al., 2006, Smith } \\
\text { et al., } 2005 \text {. } \\
\text { Skuse et al., } \\
\text { 1997, Bianconi } \\
\text { et al., 2011. }\end{array}$ \\
\hline $12 \mathrm{p} 13.33$ & CACNAIC & Timothy syndrome & $\begin{array}{l}\text { The calcium channel } \\
\text { gene CACNA1H - } \\
\text { Missense mutations }\end{array}$ & $\begin{array}{l}\text { Not } \\
\text { decisive }\end{array}$ & Depil et al.,2011 \\
\hline $15 q 11.2$ & UBE3A & Angelman syndrome & $\begin{array}{lr}\text { Reduced expression of } \\
\text { UBE3A } & \text { maternally } \\
\text { expressed } & \text { gene, } \\
\text { Maternal } & \text { deletion, } \\
\text { paternal } & \text { UPD, IC }\end{array}$ & $\begin{array}{l}\text { Not } \\
\text { decisive }\end{array}$ & $\begin{array}{l}\text { Guffanti et } \\
\text { al.,2011, Nurmi } \\
\text { et al.,2001. }\end{array}$ \\
\hline
\end{tabular}




\begin{tabular}{|c|c|c|c|c|c|}
\hline & & & $\begin{array}{l}\text { deletions, epimutations, } \\
\text { mutations of UBE3A }\end{array}$ & & \\
\hline $16 p 13.3$ & TSC2 & $\begin{array}{l}\text { Type II, Tuberous Sclerosis } \\
\text { type II }\end{array}$ & $\begin{array}{l}\text { Mutation in gene TSC2 } \\
\text { and hyper activation of } \\
\text { the downstream mTOR } \\
\text { pathway, resulting in } \\
\text { increased cell growth } \\
\text { and proliferation. }\end{array}$ & $\begin{array}{l}\text { Not } \\
\text { decisive }\end{array}$ & $\begin{array}{l}\text { Showbrige et } \\
\text { al.,2010 }\end{array}$ \\
\hline $17 q 11.2$ & NF1 & Neurofibromatosis & $\begin{array}{l}\text { within the intron-27 } \\
\text { Polymorphisms, which } \\
\text { includes the (AAAT)(n) } \\
\text { and two(CA)n }\end{array}$ & $\begin{array}{l}\text { Not } \\
\text { decisive }\end{array}$ & $\begin{array}{l}\text { Marui } \\
\text { al.,2004 }\end{array}$ \\
\hline Xp21.2 & $D M D$ & Duchennemusculardystrophy & $\begin{array}{l}\text { Mutations of DMD } \\
\text { gene leads to the } \\
\text { absence of dystrophin } \\
\text { protein }\end{array}$ & $\begin{array}{l}\text { Not } \\
\text { decisive }\end{array}$ & $\begin{array}{l}\text { Klymiuk } \\
\text { al.,2011 }\end{array}$ \\
\hline Xp21.3 & $A R X$ & LIS, XLID, EPI, ASD & $\begin{array}{lr}\text { Naturally } & \text { occurring } \\
\text { missense } & \text { and } \\
\text { Nonsense } & \text { mutations, } \\
\text { polyalanine } & \text { tract } \\
\text { expansions } & \text { also } \\
\text { mutations } & \\
\end{array}$ & $\begin{array}{l}\text { Not } \\
\text { decisive }\end{array}$ & $\begin{array}{l}\text { Valerio } \\
\text { al.,2009 }\end{array}$ \\
\hline $\mathrm{Xq} 27.3$ & $F M R 1$ & Fragile $X$ syndrome & $\begin{array}{l}\text { DNA methylation of } \\
\text { FMR1 gene, FMR1 } \\
\text { expression reduced, } \\
\text { CGG repeat expansion }\end{array}$ & $\begin{array}{l}60-67 \% \text { in } \\
\text { males, } \\
23 \% \text { in } \\
\text { female }\end{array}$ & $\begin{array}{l}\text { Bianconi } \\
\text { al.,2011 }\end{array}$ \\
\hline $\mathrm{Xq} 28$ & MECP2 & Rett syndrome & $\begin{array}{l}\text { Mutations in MECP2 } \\
\text { and CDKL5 }\end{array}$ & $\begin{array}{l}\text { Overlap in } \\
\text { symptoms } \\
\text { Infancy }\end{array}$ & $\begin{array}{l}\text { Coutinho et al., } \\
\text { 2007Shibayama } \\
\text { et al.,2004. }\end{array}$ \\
\hline
\end{tabular}

Abbreviations: ADHD - attention deficit hyperactivity disorder; EPI - epilepsy ;LIS - lissencephaly; OCD obsessive compulsive disorder; TS - Tourette syndrome; XLID, X-linked intellectual disability.

Table 2.Genetic alteration associated with ASD

\begin{tabular}{|l|l|l|l|}
\hline Gene & Genetic alteration & Location & Reference \\
\hline FMR1 & $\begin{array}{l}\text { CGG repeat (45 to 55) in FMR1 alleles termed } \\
\text { as intermediate mutation ,permutation (55 to } \\
\text { 200) and full mutation (>200) }\end{array}$ & Region 5'untranslated & $\begin{array}{l}\text { Maddalena et al.,2011, } \\
\text { Pfeiffer et al.,2009, Tan et } \\
\text { al.,2009. }\end{array}$ \\
\hline MECP2 & T158M, T158A & Missense mutation & Goffin et al.,2011 \\
\hline CNTNAP2 & G731S, I869T & 3709delG & Strauss et al.,2006 \\
\hline & R1119H, D1129H, I1253T, T1278I & Exon 14, 17,20, 21, 23, & Bakkaloglu et al.,2008 \\
\hline & 2275A & Exon 6 & O’Roak et al.,2011
\end{tabular}




\begin{tabular}{|c|c|c|c|}
\hline PTEN & Deletion & Exon 2 & Conti et al.,2011 \\
\hline CACNA1C & G406R & Missense mutation & Splawski et al.,2006 \\
\hline UBE3A & D15S122 & $5^{\prime}$ end of UBE3A & $\begin{array}{l}\text { Guffanti et al.,2011, } \\
\text { Nurmiet al.,2001. }\end{array}$ \\
\hline TSC2 & SNP & Intron 4, 9; exon 40 & Serajee et al.,2003 \\
\hline NF1 & SNP & Intron 27 & Marui et al.,2004 \\
\hline NLGN3 & R451C & Missense mutation & \begin{tabular}{|l|} 
Jamain et al.,2003, \\
Comoletti et al.,2004.
\end{tabular} \\
\hline NLGN4 & 1186insT & Frameshift mutation & Comoletti et al.,2004. \\
\hline \multirow[t]{2}{*}{ NRXN1 } & De novo $320-k b$ deletion & \begin{tabular}{|l|}
$\begin{array}{l}\text { Promoter and initial } \\
\text { coding exons }\end{array}$ \\
\end{tabular} & $\begin{array}{l}\text { Friedman et al.,2006, Zahir } \\
\text { et al., } 2008\end{array}$ \\
\hline & Missense structural variant & \begin{tabular}{|l|l|}
$\begin{array}{l}\text { Neurexin1ß signal } \\
\text { peptide region }\end{array}$ & \\
\end{tabular} & Feng et al.,2006 \\
\hline FOXP1 & De novo intragenic deletion & Exons 4-14 & Hamdan et al.,2010 \\
\hline \multirow[t]{2}{*}{ FOXP2 } & Del CAA; & Exon 5 & $\begin{array}{l}\text { Li et al.,2005 } \\
\text { Mukamel et al.,2002 }\end{array}$ \\
\hline & Frequency of the TT allele & Intron 15 & \\
\hline GRIK2 & SNP & M867I & Jamain et al.,2002 \\
\hline \multirow[t]{3}{*}{ SHANK3 } & De novo Q321R & Stop codon & Durand et al.,2012. \\
\hline & 1-bp insertion & Exon 11 & Kolevzon et al.,2011 \\
\hline & De novo 7.9-Mb deletion & 22q13.2-qter & Chen et al.,2010. \\
\hline
\end{tabular}

Tab le 3. Rare disorders with ASD

\begin{tabular}{|c|c|c|c|c|}
\hline Gene & Chromosome & $\begin{array}{l}\text { Phenotype } \\
\text { (human/mouse) }\end{array}$ & Mechanism involved in ASD & Reference \\
\hline \multirow[t]{3}{*}{ NRXN1 } & $2 \mathrm{p} 16.3$ & $\begin{array}{l}\text { ASD, ID,SCZ, } \\
\text { Dealy in } \\
\text { Language }\end{array}$ & $\begin{array}{l}320-\mathrm{kb} \text { De novo deletion, removes the } \\
\text { promoter initial coding exons of the NRXN1 } \\
\text { gene leads to deletion of of neurexin } 1 a\end{array}$ & Zahir et al.,2008 \\
\hline & & & $\begin{array}{l}\text { Neurexin } 1 \mathrm{~b} \text { signal peptide region, Missense } \\
\text { structural variants }\end{array}$ & Feng et al.,2006. \\
\hline & & & CNV & $\begin{array}{lr}\text { Glessner } & \text { et } \\
\text { al.,2009, Szatmari } \\
\text { et al.,2007 }\end{array}$ \\
\hline & & & In / near NRXN1gene occurs Translocations & et al.,2008, \\
\hline
\end{tabular}




\begin{tabular}{|c|c|c|c|c|}
\hline & & & and intragenic rearrangements & $\begin{array}{l}\text { Wisniowiecka et } \\
\text { al.,2010 }\end{array}$ \\
\hline FOXP1 & $3 p 13$ & ID, ASD, SLI & $\begin{array}{l}\text { FOXP1, exons } 4-14-\text { De novo intragenic } \\
\text { deletion and nonsense mutation binding } \\
\text { domain }\end{array}$ & $\begin{array}{l}\text { Hamdan } \\
\text { al.,2010 }\end{array}$ \\
\hline GRIK2 & $6 q 16.3$ & $\begin{array}{l}\text { ASD, Recessive } \\
\text { ID }\end{array}$ & $\begin{array}{l}\text { GRIK2 gene -SNP1 \& SNP2 associated with } \\
\text { autism }\end{array}$ & Casey et al .,2011 \\
\hline \multirow[t]{4}{*}{ FOXP2 } & 7q31.1 & ASD, SLI & $\begin{array}{l}\text { Directly bind intron } 1 \text { of the CNTNAP2 gene } \\
\text { also regulate its expression }\end{array}$ & Casey et al .,2011 \\
\hline & $11 p 15.5$ & $\begin{array}{l}\text { Beckwith- } \\
\text { Wiedemann } \\
\text { syndrome }\end{array}$ & $\begin{array}{l}\text { Due to DNA methylation at paternal allele of } \\
\text { IC } 1 \text {, IGF2 is over expressed paternally \& } \\
\text { suppression of maternally expressed } \\
\text { suppressing factor CDKN1C }\end{array}$ & Kent et al.,2008 \\
\hline & $15 q 11-q 13$ & $\begin{array}{l}\text { Prader-Willi } \\
\text { syndrome }\end{array}$ & $\begin{array}{l}\text { At15q11-13, Paternal deletions, maternal } \\
\text { UPD, IC deletions and epimutations, SNRPN } \\
\text { disruption due to translocations }\end{array}$ & $\begin{array}{l}\text { Descheemaeker et } \\
\text { al.,2006. } \\
\text { Veltman } \\
\text { al.,2004 }\end{array}$ \\
\hline & & $\begin{array}{l}\text { Maternal } \\
\text { duplication of } \\
\text { 15q11-13region }\end{array}$ & 15q11-13 region Maternal duplications & Hogart et al.,2010 \\
\hline SHANK3 & $22 q 13.33$ & ASD & $\begin{array}{l}\text { An intronic donor splice site mutation, one } \\
\text { missense mutation in the coding region }\end{array}$ & $\begin{array}{l}\text { Gauthier } \\
\text { al.,2010. }\end{array}$ \\
\hline NLGN4X & & $\begin{array}{ll}\text { ASD, ID, TS, } \\
\text { ADHD }\end{array}$ & Frameshift mutation (1186insT) & $\begin{array}{l}\text { Comoletti } \\
\text { al.,2004. }\end{array}$ \\
\hline NLGN3 & Xq13.1 & ASD & $\begin{array}{l}\text { R451C mutation within the neuroligin } 3 \\
\text { esterase domain }\end{array}$ & $\begin{array}{l}\text { Jamain et al.,2003, } \\
\text { Comoletti } \\
\text { al.,2004. }\end{array}$ \\
\hline
\end{tabular}

Abbreviations: ADHD- attention deficit hyperactivity disorder; ID- intellectual disability; TS- Tourette syndrome; SCZ- schizophrenia; SLI- speech and language impairment;.

Genome screens, linkage data in animal models connects the oxytocin receptor at chr. 3p25-p26 [37]. Infrequent manifestation of a unique genetic syndrome has been demonstrated by studies in families with ASD, due to the disruptions of the NLGN4 gene on chr. Xp22 and also maternal duplications of the chromosome on chr. 15q11-13 region.

\section{Brain volume and Autism}

ASD is truly not a disease but it is a syndrome. Scientists also have discovered irregularities which can occur during prenatal development in the brain architecture markedly in the corpus callosumconnects and expedites communication between the right and left hemispheres of the brain, amygdala is responsible for social behavior, emotions and cerebellum-controls, coordinates motor 
activity, balancing the posture. In addition, there is no co-biochemical marker for ASD,although25\% of subjects show hyperserotonemia [38].Imbalanced level of neurotransmitters are chemicals, aids the neurons to connect with each other, for example - serotonin , can modify emotions, normal behavior, and the activator of the neurons is glutamate are also blamed for the autistic behaviors. The National Alliance for Autism Genome Project is a collective work, carried out by many national-wide research institutions are probing the whole human genome to find the one that triggers autism. In the 1980s, the biological basisof autism was identified. Dr. Eric Courchesne et al., for the first time showed that, cerebellum is the most and usually affected part of the brain in an autistic individual [39]. The group has examined the cerebral lobes in the early life of an autistic child [40].In the first study, they have established that, at birth the total brain volume remained normal in children who later were developed autism. From 2 to 4 years of age, majority of the children developed larger brain volumes and the cerebral volume was significantly higher whencompared to controls. The autistic children of older age and adults have not revealed any disproportionategrowth in these regions advocates that, early hyperplasia in the beginning stage of autism is shadowed by a plateau during which a catch up growth of the brain in a healthy person ensues. The project work also has observed the cerebral lobes in the early stages of autism [40].

In 2003, Courchesne et al., have reported that, abnormal brain growth in autistic children can start by one year of age or even before that. The initial enlargement of the frontal lobesappreciated in 2 to 4 year-old autistic children and seems to be more and nearer to the normal average in the occipital lobes, hence orbital cortex and precentral gyrus are noted normal in size [41].Autistic children between ages 3 to 9 , showed an reversed association of development between frontal lobe volume and size of the cerebellar vermis with reduced Purkinje cell numbers [42]. The early developmental findings show that, atypical growth patterns of the neurons causes a number of changes in the autistic brain structure and its function. The prevalence of children diagnosed with ASD is on the rise, hence the call for the MT services for this populationis also increasing [43]. Xue Hua and colleagues from UCLA found that uncharacteristic growth of the brain areas involved in social,communication and behavior skills illustrates autism. The researchers practiced a conventional brain-imaging scan known as T1-weighted MRI, which catches the structural changes of a developing brain [44].

\section{Function of the brain in Autism}

In late 20th century, the Functional Magnetic Resonance Imaging (fMRI) technique recognized that autism is caused by the brain's abnormal functioning $[45,46,47,48]$ and this can be related to the genetic problems. Magnetic Resonance Imaging (MRI) technique shows reduced activity in the brain areas of a group of people with high functioning Autism while watching line drawing animation and normal activity among the non- autistic control group [49]. 


\subsection{Mind and the brain}

In theory of mind (TOM) processing, brain areas are connected in a different way between normal and ASD individuals. ASD person have fewer connections in the superior temporal area on the right side of the brain and in the superior medial frontal area. Social impairments in autism may be caused by the poor frontal-posterior connectivity and the language comprehension is performed by a network of frontal and posterior areas, and the weakened connectivity between these could harm this network's functioning. A study by Marcel [49] provides new evidence about the association between brain connectivity and social functions in ASD. The study evaluates the ToM, which is the ability to understand one's own mental state and others. The researchers investigated how children with ASD's ToM skills related to brain connectivity and discovered that autistic children have disruptions in the brain's ToM web, which may describe some of the deficits in the social aspects of autism disorder. As yet, the cure for Autism is unknown, if someone attains speech and the IQ is greater than 50 , the prognosis about their future is good, but below this they have to lead a dependent life.

\subsection{ASD Brain and Music}

Autism is described by expressive language and communications deficits, while some individuals totally deficient in functional speech [50]. ASD children lack the ability to precisely process and infer auditory information [51] and display strong interest in studies related to music $[52,53]$. Wigram et al., have discussed about the use of MT in special needs education background, where music therapists can work with someone with learning disabilities, challenging behavior, reduced social skills, and connected to other psychological conditions [54]. They assured that music therapists can practice music, and through it they are able to fulfil the demands of the client. Lai and colleagues have reported that, children aged 5 to 22 with ASD, when exposed to song, developed robust stimulations of the speech and auditory areas of the cortex, which in turn corresponded well with the activation of frontal-posterior networks, exceeding the activating potential of the neurotypical children. Children with ASD have inherent musical processing skills and this has been proved by many researches [55].Also they have enhanced sensitivity to pitch and melody $[56,57,58]$. If the affected ASD brain can perceive the musical stimuli in a better way, it is also possible that music can enhance learning in those areas which are under-connected. The rhythm and structural components of music assist children with ASD to consolidate, foresee, and rejoin to their surroundings. Many studies have proved that, a deficiency in brain signaling system caused motor deficit of the ASD brain which prevents an affected individual to respond adequately to their milieu, leads to an incompetence to plan, start and successfully finish a motor sequence $[59,60]$. Hardy and LaGasse have reported that, rhythmic music offers a stimulus that has been widely shown in the rehabilitation related literatures [61]. MT due to the nonverbal, nonthreatening nature is very organizing for the brain and naturally provides a structured way to present information, so that optimal learning can be achieved with the help of a trained music therapist. It has been developed as an effective medium for the autistic children to gain therapeutic access, to an extent where coordination can be achieved satisfactorily. It can complement, strengthen, or restrain emotions that arise from confusion of initiatives and can gain access into the 
domain of isolation that brings communication from a silent and isolated autistic child. The two key goals intended to achieve when MT is recommended for autistic individuals are, improving communication, language and socio-behavioral skills [62].

Described by Dr. Andreas Rett in 1964, RTT is known to the world in 1983, after the formerly publication by Dr. Bengt Hagberg. RTT is a neurological disorder misunderstood as autism, cerebral palsy or non- specific delay of the developmental milestones, caused by a defect in the regulatory MECP2 gene on the $X$ chromosome. RTT is reported exclusively in female children and occurs 1 in 10,000 to 1 in 23,000 female births. Until 6-18 months of age, developmental milestones appear normal and proceeds with loss of speech and motor skills. People with RTT have favorite pieces of melody and express a strong reaction while listening to a favorite tune of their interest. This unique quality of the RTT group has been studied by the investigators in Sweden and USA [63,64].Both studies have revealed the fact that, the RTT group had specific musical favorites as reported by people who take care of them.

AS belongs to ASD, but autism or high functioning autism and AS is not clinically the same [65]. The predominant differences are, people with AS show normal or outstanding knowledge in a dominion in which they are interested, also they often prefer to talk about their interest to others in the form of a deep monologue, not considering whether they receive a reply or not [66]. James (2006) reported the relationship between music and people with AS by quoting the work of composer Bela Bartok and pianist Glenn Gould, thought to have had Asperger's syndrome [67]. AS disorder is commonly identified by the socialization deficits, low measures on adaptive behaviors and executive dysfunctions which makes them struggle to achieve daily tasks and therefore establishing reason for MT interventions. Structured instrumental play, interactions through music and social skills training have been successfully employedas an effective MT intervention [68].

In ADHD the executive dysfunction and attention deficiency are the core part of the cognitive symptoms. A study involving brain imaging shows that musical training is linked with improved executive functioning in kids and adults [69]. In ADHD there tends to be a low level of brain messenger chemical known as dopamine. One reason that MT thought to help improve ADHD symptoms is that, it seems to increase the dopamine levels. Childhood Disintegrative Disorder was initially described by Thomas Heller in 1908. Heller's syndrome, is a complex disintegrative psychosis, prevalence of less than 1 out of every 100,000 children, grouped with the PDDs and is a known common disorder of autism. The onset is late , >3 years of age with delayed developmental mile stones, social and motor skills gradually regresses with the loss of speech and other skills until the characteristics of autism become apparent [70].

\section{The power of music on the brain}

The Human brain evolution demonstrates the ontogeny of the baby's clucking during the development proves that musical vocalization precedes spoken words and may be a repetition of the phylogeny of our ancestral species. In his book, named as "Music as Heard" Thomas Clifton states that, music is an well-organized agreement of sounds and silences, establishes a firm 
reciprocal relation between a person, his behavior, and a sounding object [71].The treatment modality of MT is based on its auditory and temporal characteristics which are unique in nature. The organized structure of music at varying intensity in specific combinations can be used to produce change in a targeted population needs special care. Research in the areas of neurological function provides evidence that the links between music and emotion are processed in the right side of the brain $[72,73,74]$. This association may have developed through processing the environmental acoustic stimuli and emotionally adaptive responses. Joseph stated that "It is possible that right hemisphere dominance for music may be an outgrowth of its capacity to discern and recognize environmental acoustics as well as its ability to mimic these and other nonverbal and emotional nuances". Further studies have documented that, someone with left hemisphere damage is unable to communicate verbally or distinguish words, but they can sing a tune [73]. Thus music has the potential to provide a form of compensation and also facilitates language development for those with language impairments.

\section{Targeted areas of music therapy for ASD individuals}

* Non Verbal to Verbal Communication - MT can enable those without verbal language in the development of verbal communication and express themselves non-verbally, improves speech, and language skills and socialization with peers [75].Children participated well in collective interactive academic reading sessions when combined with music [76].

* Cognitive Function - Recent studies established that music engages various part of the brain that overlay the human mirror neuron system [77].The brain comprehends music enhances communication skills. Music as an influential means supports quantifiable changes in cognitive social skills [68].

*Behavioral Problem - The hall mark of autism is repetitive behavior. The rhythmic element of music organizes the sensory systems, process the auditory, sensory-motor, gross and fine motor skills.Studies established that MT can increase the engagement behavior [76], reduces autistic-like behaviors [78], and establishes behavioral change accomplished through social stories using music [79].

*Socialization and Interaction - Social skill deficits are much appreciated as central characteristics of ASDs. MT augments the interpersonal relation and mutuality in a joint play, answering to each other, turn-taking with ASD person, address their individual style of communication, increase joint attention behaviors [80,81], social greeting routines [82], communication skills $[62,83,84]$, peer interactions [85].

*Emotional- Listening to the music creates an emotional impact on people well documented [86].MT aids individuals with ASD to identify, understand their emotions [87] and emotional engagements [88].The hypothesis of arousal and mood [89] suggests, if music listening can disturb cognitive abilities, this could be due to changes in provocation or mood of a person who listens to music [90]. 
* Regulation of mind: As ASD person has native musical talents, MT therapy offers them pleasure which turns in to a positive experiences $[56,57,58]$.

* Music and aesthetic experience: Music in an art form, foster aesthetic developments and is recognized as an equivalent of human beings innermost mind, permitting them to discover its disciplined nature [91].

\section{Time line of Music therapy for children with autism spectrum disorder}

The time line of MT for ASD children begins around 1940 [43]. In 1940s, music therapists and volunteers worked with ASD children in psychiatric hospitals, institutions, and public schools mostly funded by the government. Use of MT as a holistic treatment of psychiatric disorders has demonstrated improvements of socially acceptable behaviors. In 1944, Michigan State University started to offer the primaryMT degree program in the globe. MT became more widespread in the 1950s and 1960s in the UK. In 1950 the National Association for Music Therapy (NAMT) has been organized, the music therapists standardized the protocol for MT and made it possible as a regular treatment for autism in the systematic music classrooms [43]. In 1952, Gilman and Paperte reported MT as being successful in the psychiatric treatment of mental disorders by accomplishing the following: ability to grasp attention by rising its span, improves re-socialization, power of diversion and substitution, modifies the mood, motivates pictorially and intellectually, reduces internal tensions, facilitate self-expression [92].Sherwin (1953) noted that children with autism were keenly interested in music, revealed extraordinary ability to reproduce familiar musical sounds and fragments of music accurately and predisposition to sing differently from average children [93].In 1960s, music therapy to recognize the need for establishing goals of MT for ASD children. Thaut wrote a protocol for treating autistic children, diagnostic criteria for autism and related MT and following this, standards were established for documenting music therapy sessions [94].

The US law 94-142 was revised in 1990, qualifying children with autism under this law. The structured teaching via the TEACCH (Treatment in Education of Autistic and Related Communication Handicapped Children) method was developed by Professor Eric Schopler with many of his colleagues at the University of North Carolina at Chapel Hill [95]. It is a therapeutic tool to help autistic individuals comprehend their environs, relies on five basic principles: Physical and Visual structures, Scheduling, Work system and Routine which has been appraised by many researchers [96]. TEACCH method is a family-centered, evidence-based practice for autism, was applied to MT. In 1993, the Performance and Results Act by the government stated that, it is necessary for all national programs to identify their aims and measure their outcomes in a quantifiable way for MT in children with Autism. In 2000, Thaut developed the Rational-Scientific Mediating Model (R-SMM) to conduct systematically high quality research in MT with the goal of forming evidence based theoretical foundations and procedures [97]. According to this model, music therapists attempt to find a response to music which can be applied in a setting without music. He also developed the Transformational Design Model (TDM) to ignore music therapy that is not goal-driven. Aims are defined by assessing the requirement of the client, translated into nonmusical therapeutic exercises and then the music therapist translates this into a music therapy application [97]. Brownwell applied 
the TDM process to a study of social stories that were musically adapted. Primarily, he assessed the needs of the client, then established that social stories were an effective nonmusical therapeutic exercise and finally used prescriptive songs to music therapy [79]. The model tried to identify treatment goals and assess their outcomes and is designed for an interdisciplinary team of doctors, therapists, and other practitioners involved in the treatment for ASDs [98]. Public Law 94-142 was revised in 2004, mandating that the educational techniques used to treat disabled children should be evidence based.

The AMTA organized the MT and Autism Task Force/Think Tank in 2007 focused on evidence based practice, clinical research models, assessment models, with an aim of guiding the future of MT and autism. Katagiri conducted study to understand the emotions of autistic children by exploring the effect of teaching background music [87]. All of the children showed significant improvements in their understanding of various emotions, representing a specific emotion in question. The study reports, music listening may be a helpful resource for understanding the emotions of autistic children. Lim applied R-SMM in paralleling perception of music to perception of speech and language [99]. In a study, Lim looked at speech construction in ASD children, after receiving either music or speech training. The results revealed that all of the children had improved verbal skills. However, the low-functioning children with Autism showed more significant improvements with music training than with speech training [83]. Wan et al., have reported that singing and playing music engages various part of the brain related to language abilities and enhances the language, social, and motor skills [77]. Another study demonstrated that, production of speech in children with Autism could be improved by incorporating music into Applied Behavioral Analysis Verbal Behavior training - ABA VB [84].

Early literature describes a common psychoanalytic method that, how ASD children were more willingly engaged by musical experiences than in other atmospheres [100]. Considering the core impairments of ASD, seven broad goals of MT for ASD children have been defined in the literature: communicative skills, social interaction, behavior change, emotional improvement, motor skills, day to day activities and pre academic skills [43]. The significance and efficacy of MT intervention for ASD children have been researched thoroughly and the studies have highlighted the part of MT as a diagnostic and clinical assessment tool. MT assessment among children has its own limitations and weaknesses. The Cochrane review titled 'Music Therapy for Autistic Spectrum Disorder' [101] analyzed studies related to $\mathrm{MT}$, the outcomes were promising and revealed that MT significantly improved the inabilities faced by the ASD children aged between two and nine years. As the sample size was small, for future studies a large number of participants, well- developed diagnostic tools and blinded assessors are recommended. Two most recent randomized controlled studies [102,103] used relevant MT methods to clinical practice showed vital findings, hence this certifies the role of MT for autistic children. Many clinical reports, case studies, single group studies and case series studies proved that the main issues of autism disorder improved over the application of improvisational MT. The meta-analysis result of several studies [104] about the effectiveness of MT with encouraging outcome and another study has reported a statistically and clinically significant role of MT for prematurely delivered neonates in the neonatal intensive care unit [105]. 


\section{Conclusion}

MT has been demonstrated as a therapeutic modality and the inherent potential of MT can be practiced in special education settings and medical services. The initial randomized controlled trials (RCT) of group music therapy intervention for ASD children provided evidence that music therapy group (MTG) sessions may improve joint attention and eye gaze toward others and served as a basis for further studies on this topic. The existing literature and a methodical review of several studies suggest, MT is a promising exercise for ASD. Due to various procedural restrictions of previous studies and the raising number of ASD population mandates intensive research, high quality RCTs with enough sample size to achieve a wide spread productive measures. One of the most prominent needed areas for children with ASD lies in verbal and nonverbal communication and various studies have reported that MT interventions can effectively improve them. Besides, as the measurement tools can impact the research outcomes immensely, by increasing their standardization in ASD research can achieve more unambiguous results pertaining to clinical medical practice and in other health care professions.

\section{Acknowledgment}

I express my gratitude and my sincere regards to the group leader and the co-authors in the Department of human genetics and molecular biology, Bharathiar University, Coimbatore, Tamil Nadu, India.

\section{Conflict of interest}

The authors declare no conflict of interest.

\section{REFERENCES:}

1.RoiaRafieyan MA, MT-BC and Rose Ries, MD, A Description of the Use of Music Therapy in Consultation-Liaison Psychiatry, Psychiatry (Edgmont). 2007 Jan; 4(1): 47-52.

2.American Music Therapy Association, What is music therapy? 2005; http:// www. Music therapy .org/about/music therapy/ Accessed 27.7.2016.

3.Forsblom A, Laitinen S, Sarkamo T, Tervaniemi M. Therapeutic role of music listening in stroke rehabilitation. Annals of the New York Academy of Sciences. 2009; 1169:426-430.

4.Yinger, O. S., and Gooding, L. Music therapy and music medicine for children and adolescents. Child Adolesc Psychiatr Clin N Am. 2014 Jul; 23(3):535-53. doi: 10.1016/j.chc.2013.03.003

5.Mrázová, M., and Celec, P.A systematic review of randomized controlled trials using music therapy for children. J. Altern. Complem. Med. 2010; Oct ; 16, 1089-1095. doi: 10.1089/acm.2009.0430

6.Chan MF, Chan EA, Mok E, Kwan, Tse FY. Effect of music on depression levels and physiological responses in community-based older adults. International Journal of Mental Health Nursing. 2009;18: 285-294. 
7.Gaser C, Schlaug G. Brain structures differ between musicians and non-musicians. Journal of Neuroscience. 2003;23: 9240-9245.

8.Kleber B, Veit R, Birbaumer N, Gruzelier J, Lotze M. The brain of opera singers: Experience-dependent changes in functional activation. Cerebral Cortex. 2009; August 19; DOI:10.1093/cercor/bhp177.

9.Catherine Y. Wan, Theodor Rüber, AnjaHohmann, and Gottfried Schlaug, The Therapeutic Effects of Singing in Neurological Disorders, Music Percept. 2010; Apr 1; 27(4): 287-295. doi: 10.1525/ mp. 2010.

10.Ozdemir E, Norton A, Schlaug G. Shared and distinct neural correlates of singing and speaking. Neuroimage.2006;33:628-635.

11.Thaut M. Robert F. Unkefer Academy of Neurologic Music Therapy". The Center for Biomedical Research in Music at Colorado State U. Accessed 27.7.2016.

12. Howells, John G.; Osborn, M. Livia. A reference companion to the history of abnormal psychology. Greenwood Press. Westport, CT: Greenwood, 1984; ISBN 978-0-313-24261-8.

13.Gouk, Penelope, in Viet Erlmann, ed., Hearing Cultures: Essays on Sound, Listening and Modernity. Oxford: Oxford University Press.2004; pp. 87-105.

14.McFerran, K., J. Y. Lee, M. Steele, and A. Bialocerkowski. "A Descriptive Review of the Literature (1990-2006) Addressing Music Therapy with People Who Have Disabilities." Musica Humana (Journal of Hte Korean Institure of Musicology) 2009;1 (1): 45-80.

15.Jellison, J. A. "A Content Analysis of Music Research with Disabled Children and Youth (1975-1999): Applications in Special Education." In Effectiveness of Music Therapy Procedures: Documentation of Research and Clinical Practice. edited by AMTA, Silver Spring, MD: American Music Therapy Association. 2000; pp 167-229.

16.Alicia Clair Gibbons and George N. Heller, Music Therapy in Handel's England: Browne's Medicina Musica, 1729, College Music Symposium, 1985,vol.25. http://symposium.music.org/index.php.

17.Rorke, M. A. Music and the wounded of World War II. Journal of Music Therapy, 1996;33(3), 189207.

18.Tyson, F. Psychiatric Music Therapy, Creative Arts Rehabilitation Center. New York, USA, 1981.

19.Kanner, L. (1943). Autistic Disturbances of Affective Contact. Nervous Child, 1943;Vol 2, 217-250.

20.Asperger $\mathrm{H}$; tr.; annot. Frith U "'Autistic psychopathy' in childhood".InFrith U. Autism and Asperger syndrome.Cambridge University Press.1991; pp. 37-92. ISBN 0-521-38608-X.

21.Grinker, R. Unstrange Minds: Remapping the World of Autism. Basic Books, New York: USA, 2007; pp $62-63$. 
22.Tharpe, A. M., Bess, F. H., Sladen, D. P., Schissel, H., Couch, S., \& Schery, T. Auditory characteristics of children with autism. Ear and Hearing, 2006;27(4), 430-441.

23.Kim YS, Fombonne E, Koh YJ, Kim SJ, Cheon KA, Leventhal BL.,A comparison of DSM-IV pervasive developmental disorder and DSM-5 autism spectrum disorder prevalence in an epidemiologic sample. $J$ Am Acad Child Adolesc Psychiatry. 2014 May; 53(5):500-8.

24.Rapin, I. Autism. N Engl J Med, 1997; 337(2), 97-104. doi: 10.1056/ NEJM 199707103370206.

25.Cohen, D., Pichard, N., Tordjman, S., Baumann, C., Burglen, L., Excoffier, E., Lazar, G., Mazet, P., Pinquier, C., Verloes, A., Heron, D. Specific genetic disorders and autism: clinical contribution towards their identification. J. Autism Dev. Disord. 2005; 35, 103-116.

26. Atladóttir HO, Thorsen $\mathrm{P}, \varnothing$ stergaard L, et al. Maternal infection requiring hospitalization during pregnancy and autism spectrum disorders. J Autism Dev Disord. 2010; 40(12):1423-1430.

27. Mundy P., Crowson M. Joint attention and early communication: Implications for intervention with autism. J. Of Autism and Developmental Disorders.1997; 27, 653-675.

28.Dawson G, Toth K, Abbott R, Osterling J, Munson J, Estes A, et al. Early social attention impairments in autism: Social orienting, joint attention, and attention in autism. Developmental Psychology.2004; 40:271-283.

29.Bodfish JW, Symons FJ, Parker DE, Lewis MH, Varieties of repetitive behavior in autism: comparisons to mental retardation. J Autism Dev Disord. 2000 Jun; 30(3):237-43.

30.Boyd BA, McDonough SG, Bodfish JW, Evidence-based behavioral interventions for repetitive behaviors in autism. J Autism DevDisord. 2012 Jun;42(6):1236-48. doi: 10.1007/s10803-011-1284-z.

31.Lo-Castro, A., Benvenuto, A., Galasso, C., Porfirio, C., \&Curatolo, P. Autism spectrum disorders associated with chromosomal abnormalities. Research in Autism Spectrum Disorders. 2010; 4, 319-327.

32.Risch N, Spiker D, Lotspeich L, Nouri N, Hinds D, Hallmayer J et al. A genomic screen of autism: evidence for a multilocus etiology. Am J Hum Genet. 1999; 65: 493-507.

33.Folstein SE, Rosen-Sheidley B. Genetics of autism: complex aetiology for a heterogeneous disorder. Nat Rev Genet. 2001; 2: 943-955.

34.William M. Brandler et al., Frequency and Complexity of De Novo Structural Mutation in Autism. The American Journal of Human Genetics. 2016; DOI: 10.1016/j.ajhg.2016.02.018.

35.Veenstra-Vanderweele J, Christian SL, Cook Jr EH. Autism as a paradigmatic complex genetic disorder.Annu Rev Genomics Hum Genet. 2004; 5: 379-405. 
36.Trikalinos, A Karvouni, E Zintzaras, T Ylisaukko-oja, L Peltonen, I Järvelä and J P A loannidis, A heterogeneity-based genome search meta-analysis for autism-spectrum disorders. Molecular Psychiatry. 2006; 11, 29-36. doi:10.1038/sj.mp.4001750.

37. Muhle R, Trentacoste SV, Rapinl. The genetics of autism. Pediatrics 2004; 113: e472-e486.

38. Cook EH, LeventhalBL.The serotonin system in autism.CurrOpinPediatr.1996; 8:348-354.

39.Courchesne E, Yeung-Courchesne R, Press GA, Hesselink JR, Jernigan TL. Hypoplasia of cerebellar vermal lobules VI and VII in autism,Neuropsychology Research Laboratory, Children's Hospital Research Center, San Diego, Calif. N Engl J Med. 1988 May 26;318(21):1349-54.

40.Carper RA, Moses P, Tigue ZD, Courchesne E. Cerebral lobes in autism: early hyperplasia and abnormal age effects. Neurolmage. 2002; 16: 1038-1051.

41.Carper RA, Courchesne E. Localized enlargement of the frontal lobe in early autism. Biol Psychiatry. 2005 Jan 15;57(2):126-33.

42. Matthew K. Belmonte1, Greg Allen2, Andrea Beckel-Mitchener3, Lisa M. Boulanger4, Ruth A. Carper5, and Sara J. Webb6, Autism and Abnormal Development of Brain Connectivity, The Journal of Neuroscience, 20 October 2004; 24(42): 9228-9231; doi: 10.1523/JNEUROSCI.3340-04.2004.

43. Reschke-Hernandez, A. E. History of Music Therapy Treatment Interventions for Children with Autism. Journal of Music Therapy. 2011;8(2), 169-207.

44. Xue Hua, Paul M. Thompson, Alex D. Leow, Sarah K. Madsen, Rochelle Caplan, Jeffry R. Alger, Joseph O’Neill, Kishori Joshi, Susan L. Smalley, Arthur W. Toga, and Jennifer G. Levitt. Brain growth rate abnormalities visualized in adolescents with autism. Hum Brain Mapp. 2013 Feb; 34(2): 425-436.

45.Masten, C. L., Colich, N. L., Rudie, J. D., Bookheimer, S. Y., Eisenberger, N. I., \& Dapretto, M. An fMRI investigation of responses to peer rejection in adolescents with autism spectrum disorders. Developmental Cognitive Neuroscience. 2011; 1(3), 260-270.

46. Philip, R. C. M., Dauvermann, M. R., Whalley, H. C., Baynham, K., Lawrie, S. M., \& Stanfield, A.C. A systematic review and meta-analysis of the fMRI investigation of autism spectrum disorders.Neuroscience and Biobehavioral Reviews, 2012; 36(2), 901.

47. Holt, R. J., Chura, L. R., Lai, M., Suckling, J., Von, d. H., Calder, A. J., et al. (2014). 'Reading the mind in the eyes': An fMRI study of adolescents with autism and their siblings. Psychological Medicine. 2014; 44(15), 3215-3227.

48. Kleinhans, N. M., Richards, T., Greenson, J., Dawson, G., \&Aylward, E. Altered dynamics of the fmri response to faces in individuals with autism. Journal of Autism and Developmental Disorders. 2015; 46(1), 232-241. 
49. Marcel Adam Just, Vladimir L. Cherkassky, Timothy A. Keller, Rajesh K. Kana and Nancy J. Minshew. Functional and Anatomical Cortical Underconnectivity in Autism: Evidence from an fMRI Study of an Executive Function Task and Corpus Callosum Morphometry. Cereb. Cortex. 2007;17(4):951-961. doi: 10.1093/cercor/bhl006.

50. Hudry K et al., PACT Consortium. Preschoolers with autism show greater impairment in receptive compared with expressive language abilities. Int J Lang Commun Disord. 2010 Nov-Dec; 45(6):681-90. doi: $10.3109 / 136828209034614$.

51. O'Connor K. Auditory processing in autism spectrum disorder: a review. Neuro sci Bio behav Rev. 2012 Feb; 36(2):836-54. doi: 10.1016/j.neubiorev.2011.11.008.

52. Hairston M. Analyses of responses of mentally retarded autistic and mentally retarded non autistic children to art therapy and music therapy. Journal of Music Therapy. 1990; 27:137-150.

53.Trevarthan C, Aitken K, Paoudi D, Robarts J. Children with autism. Jessica Kingsley Publishers; London: 1996.

54. Wigram T. Indications in music therapy: evidence from assessment that can identify the expectations of music therapy as a treatment for autistic spectrum disorder (ASD): meeting the challenge of evidence based practice. Br J Music Ther. 2002; 16:11-28.

55.Lai G., Pantazatos S. P., Schneider H., Hirsch J. Neural systems for speech and song in autism. Brain, 2012; 135, 961-975.

56.Bonnel A., McAdams S., Smith B., Berthiaume C., Bertone A., Ciocca V. Mottron L . Enhanced puretone pitch discrimination among persons with autism but not Asperger syndrome. Neuropsychologia.48(9),2010; 2465-2475.doi: 10.1016/ j.neuropsychologia.2010.04.020.

57.Ouimet T., Foster N. E., Tryfon A., Hyde K. L. Auditory-musical processing in autism spectrum disorders: a review of behavioral and brain imaging studies. Annals of the New York Academy of Sciences.2012; 1252(1), 325-331.

58. Stanutz S., Wapnick J., Burack J. Pitch discrimination and melodic memory in children with autism spectrum disorder. Autism. (2012); Feb;18(2):137-47. doi: 10.1177/1362361312462905.

59. Robledo J., Donnellan A. M., Strandt-Conroy K. An exploration of sensory and movement differences from the perspective of individuals with autism. Front IntegrNeurosci.2012; 6, 107.doi: 10.3389/fnint.2012.00107.

60. Torres E. B., Yanovich P., Metaxas D. N. Give spontaneity and self-discovery a chance in ASD: spontaneous peripheral limb variability as a proxy to evoke centrally driven intentional acts. Frontiers in integrative neuroscience.2013; 7, 46.doi: 10.3389/fnint.2013.00046. 
61. Hardy M. W., LaGasse A. B. Rhythm, movement, and autism: Using rhythmic rehabilitation research as a model for autism. Front IntegrNeurosci.2013; 7, 19. doi: 10.3389/fnint.2013.0001921.

62. Kaplan R. S., Steele A. L. an analysis of music therapy program goals and outcomes for clients with diagnoses on the autism spectrum. Journal of Music Therapy.2015; 42(1):2-19.

63. Houtaling, C. Music and Rett Syndrome: A Survey from the Parental Perspective. 2003; Available from ProQuest dissertations and Theses data base (UMI No.1414651).

64. Merker, B., Bergström-Isacsson, M., \& Witt Engerström, I. Music and the Rett disorder: The Swedish Rettcentre survey. Nordic Journal of Music Therapy.2001; 10(1), 42-53.

65.Rinehart, N. J., Bradshaw, J. L., Brereton, A. V., \&Tonge, B. J. A clinical and neuro behavioural review of high-functioning autism and Asperger's disorder. Australian and New Zealand journal of psychiatry. 2002; 36(6), 762-770.

66.Woodbury-Smith, M. R. \& Volkmar, F. R. Asperger syndrome. European Child and Adolescent Psychiatry.2009; 18(1), 2-11.

67. James, I. (2006). Asperger's syndrome and high achievement: Some very remarkable people, Jessica Kingsley. London, 2006.

68. Ulfarsdottir L., Erwin P. The influence of music on social cognitive skills. The Arts in Psychotherapy.1999; 26(2), 81-84.

69. Jennifer Zuk, Christopher Benjamin, Arnold Kenyon, Nadine Gaab ,Behavioral and Neural Correlates of Executive Functioning in Musicians and Non-Musicians, Published: June 17,2014. http://journals.plos.org/plosone/article?id=10.1371/journal. pone. 0099868 .

70. Sri HariCharan, Childhood disintegrative disorder, J PediatrNeurosci. 2012 Jan-Apr; 7(1): 55-57. doi: 10.4103/1817-1745.97627PMCID: PMC3401658 .

71. Clifton, Thomas. Music as Heard: A Study in Applied Phenomenology. Yale University Press. New Haven and London: 1983;ISBN 0-300-02091-0.

72. Hodges, D. Neurophysiology and musical behavior. In D. A. Hodges (Ed.), Handbook of music psychology. Dubuque, IA: National Association for Music Therapy. 1980; pp. 195-224.

73. Joseph, R. Neuropsychology, neuropsychiatry, and behavioral neurology. New York: Plenum.1990.

74. Schore, A. Affect regulation and the origin of the self: The neurobiology of emotional development. Hillsdale, NJ: Lawrence Erlbaum Associates, Inc.,1994.

75. Kern P., Aldridge D. Using embedded music therapy interventions to support outdoor play of young children with autism in an inclusive community-based child care program. Journal of Music Therapy.2006; 43, 270-294. 
76. Carnahan C., Musti-Rao S., Bailey J. Promoting active engagement in small group learning experiences for students with autism and significant learning needs. Education and Treatment of Children.2009; Vol: 32 n1 p37-61 Feb 2009.

77.Wan CY, Demaine K, Zipse L, Norton A, SchlaugG. From music making to speaking: engaging the mirror neuron system in autism. Brain Res Bull. 2010; 82: 161-168.

78. Boso M., Emanuele E., Minazzi V., Abbamonte M., Politi P. Effect of long-term interactive music therapy on behavior profile and musical skills in young adults with severe autism. Journal of Alternative and Complementary Medicine.2007; 13(7), 709-712,doi:10.1089/ acm.2006.6334.

79.Brownwell, M. D. Musically adapted social stories to modify behaviors in students with autism: Four case studies. Journal of Music Therapy.2002; 39, 117-144.

80.Kalas A. Joint attention responses of children with autism spectrum disorder to simple versus complex music. Journal of Music Therapy.2012; 49, 430-452.

81.Kim HG, Kishikawa S, Higgins AW. Disruption of neurexin 1 associated with autism spectrum disorder. Am J Hum Genet.2008; 82: 199-207.

82. Kern P., Wolery M., Aldridge D. Use of songs to promote independence in morning greeting routines for young children with autism. Journal of Autism and Developmental Disorders.2007; 37(7), 1264-1271.

83. Lim H. A. Effect of "Developmental Speech and Language Training Through Music" on speech production in children with autism spectrum disorders. Journal of Music Therapy.2010; 47, 2-26.

84. Lim H. A., Draper E. The effects of music therapy incorporated with applied behavior analysis verbal behavior approach for children with autism spectrum disorders. Journal of Music Therapy.2011; 48, 532-550.

85. Kern P., Aldridge D. Using embedded music therapy interventions to support outdoor play of young children with autism in an inclusive community-based child care program. Journal of Music Therapy.2006; 43, 270-294.

86. Schmidt, L.A. and Trainor, L.J. 'Frontal Brain Electrical Activity (EEG) Distinguishes Valence and Intensity of Musical Emotions', Cognition and Emotion.2001; 15(4): 487-500.

87. Katagiri, J. K. The Effect of Background Music and Song Texts on the Emotional Understanding of Children with Autism. Journal of Music Therapy.2009; 46(1), 15-31.

88. Kim J., Wigram T., Gold C. Emotional, motivational and interpersonal responsiveness of children with autism in improvisational music therapy. Autism, 2009;3(4), 389-409.

89.Thompson, W.F., Schellenberg, E.G. and Husain, G. 'Arousal, Mood, and the Mozart Effect', Psychological Science. 2001; 12(3): 248-51. 
90. Hallam, S., Price, J. and Katsarou, G. 'The Effects of Background Music on Primary School Pupils Task Performance', Educational Studies.2002; 28: 111-22.

91. Jo SALAS ,Music Therapy. 1990; Vol. 9, No. I, pp. I-15.

92. Gilman, L., \&Paperte, F. Music as a psychotherapeutic agent. In E. A. Gutheil (Ed.) Music and your Emotions, New York: Live right, 1952; pp. 24-55.

93. Sherwin, A. C. Reactions to music of autistic (schizophrenic) children. American Journal of Psychiatry.1953; 109, 823-831.

94. Thaut,M.H. A music therapy treatment model for autistic children. Music Therapy Perspectives.1984; 1(4), 7-13.

95. Mesibov, G.B.,Shea, V., \&Schopler, E. The TAACHH approach to Autism spectrum disorders. Kluwer Academic / Plenum Publishers. New York, USA, 2005.

96. lovannone R, Dunlap G, Huber H, Kinkaid D. Effective educational practices for students with autism spectrum disorders, Focus on Autism and Other Developmental Disabilities. 2003;18:150-165.

97. Thaut, M. H. A scientific model of music in therapy and medicine. San Antonio, TX: The University of Texas at San Antonio, USA, 2000.

98.DeLoach Walworth, D. The Use of Music Therapy within the SCERTS Model for Children with Autism Spectrum Disorder. Journal of Music Therapy.2007; 44(1), 2-22

99.Lim, H. A. Use of music to improve speech production in children with autism spectrum disorders: Theoretical orientation. Music Therapy Perspectives.2009; 27, 103-193.

100. Nordoff, P.,\&Robbins,C. Creative Music Therapy: Individualized Treatment for the Handicapped Child. John Day Co., New York: John Day Co.1977.

101. Gold, Christian, Tony Wigram, and CochavitElefant. 2006. "Music Therapy for Autistic Spectrum Disorder." Cochrane Database of Systematic Reviews Issue 2. 2006; Art. No.: CD004381. doi:10.1002 / 14651858.CD00438.

102.Gattino GS, Riesgo RDS, Longo D, Leite JCL, Faccini LS. Effects of relational music therapy on communication of children with autism: a randomized controlled study. Nord J Music Ther. 2011;20:142-154. doi: 10.1080/08098131.2011.566933.

103.Thompson, G., K. S. McFerran, and C. Gold."Family-centred Music Therapy to Promote Social Engagement in Young Children with Severe Autism Spectrum Disorder: A Randomised Controlled Study." Child: Care, Health \& Development.2013; 40 (6): 840-852. doi:10.1111/cch.12121. 
104. Whipple, J. Music in intervention for children and adolescents with autism: A meta- analysis. Journal of Music Therapy.2004; 41(2), 90-106.

105. Standley J, Music therapy research in the NICU: an updated meta-analysis. Neonatal Netw. 2012; Sep-Oct; 31(5):311-6.

C 2016 by the authors; licensee Preprints, Basel, Switzerland. This article is an open access article distributed under the terms and conditions of the Creative Commons by Attribution (CC-BY) license (http://creativecommons.org/licenses/by/4.0/). 